\title{
PENYULUH AGAMA SEBAGAI MOTIVATOR MAJELIS TAKLIM DAN IBADAH SOSIAL KEMASYARAKATAN
}

\author{
Syarif Husain
}

Balai Diklat Keagamaan Palembang

syarifhusain@gmail.com

\begin{abstract}
Abstrak
Penyuluh agama dalam peranannya sebagai motivator majelis taklim dan penggerak ibadah sosial kemasyarakatan, dalam menyampaikan pesan-pesan moral dan memberikan pencerahan terhadap anggota majelis taklim dan anggota masyarakat, dituntut agar mampu mengembangkan sumber daya manusia dan organisasi majlis taklim. Hal tersebut dilakukan agar tujuan dari pesan-pesan moral dapat berhasil guna dan berdaya guna melalui kegiatan majlis taklim, dan anggota majelis taklim menjadi berdaya dalam peranannya sebagai anggota, baik sebagai anggota majlis taklim binaan penyuluh maupun sebagai anggota masyarakat. Mengajak manusia kepada proses perbaikan akhlak, perilaku dan karakteristik Islami harus diakukan dengan jalan bijak dan pelajaran-pelajaran yang bermnfaat. Dalam tulisan ini diuraikan bagaimana peran penyuluh agama sebagai motivator majelis taklim, terutama dalam menggerakan roda organisasi kelembagaannya serta pemberdayaan jama'ahnya, sehingga majelis taklim bukan hanya mengadakan rutinitas dan ritual keagamaan saja melainkan memberdayakan majlis taklim menjadi lembaga yang bergerak dalam bidang kesejahteraan anggotanya. Kegiatan yang digerakkan oleh penyuluh agama sebagai pemotivator dalam tulisan ini diantaranya mendirikan koperasi sebagai penggerak ekonomi umat, penggerak ibadah sosial kemasyarakatan serta melakukan pembimbingan dan pendampingan pengurusan jenazah.
\end{abstract}

Kata Kunci: Motivator, ekonomi umat, ibadah sosial kemasyarakatan, dan bimbingan serta pendampingan pengurusan jenazah. 


\section{PENDAHULUAN}

Meski telah melampaui beberapa fase pergantian zaman, Eksistensi Majelis Ta'lim telah lama dan cukup kuat dengan tetap memelihara pola dan tradisi yang baik sehingga mampu bertahan di tengah kompetisi lembaga-lembaga pendidikan keagamaan yang bersifat formal. Namun sayang sekali, keberadaan majlis taklim dalam perkembangannya terutama dalam segi pemberdayaan organisasi majlis taklim dan anggota jama'ahnya tidak begitu kelihatan, bahkan terkesan monoton dan begitu-begitu saja. Pada masa dahulu dan pada saat sekarangpun masih banyak majlis taklim hanya sebatas rutinitas dan tempat ritual pengajian dan ibadah yang dikelola secara individual oleh seorang kyai sebagai top leader. Kyai merupakan penggerak organisasi yang merangkap sebagai pengajar, begitulah dari waktu ke waktu dengan zaman yang selalu mengiringinya.

Terdapat harapan-harapan baru terhadap masa depan majlis taklim ini maka pemerintah ikut serta hadir pada lembaga ini dengan lahir peraturan dan perundang-undangan, yakni PMA nomor 29 tahun 2019 tentang Majlis Taklim, maka dalam mengejawantahkan salah satu tujuan majlis taklim dalam PMA nomor 29 tahun 2019 tersebut adalah membentuk manusia yang memiliki pengetahuan agama yang mendalam dan komprehensif.

Dalam kerangka mengaplikasikan salah satu dari tujuan majlis taklim tersebut, maka penyuluh agama dituntut untuk terjun langsung membina kelembagaan majlis taklim tersebut. Harapannya adalah menjadikan majlis taklim menjadi lembaga yang berintegritas dan mempunyai program terukur da terstruktur, berdaya guna, terutama bagi anggota jama'ahnya dan lingkungan masyarakat sekitarnya.

Selanjutnya, dalam perkembangannya, untuk menggerakkan kegiatan majlis taklim dewasa sekarang ini, semestinya bukan hanya dikomandoi oleh seorang kyai saja, akan tetapi dibantu dan digerakkan oleh para penyuluh agama Islam, baik penyuluh agama Islam PNS maupun penyuluh agama Islam Non PNS. Hal ini tentu dengan tidak menafikkan eksistensi tugas dan wewenang kyai. Ini menjadi niscaya karena majlis taklim pada umumnya sudah ada dan berdiri sejak sebelum adanya penyuluh yang diangkat oleh pemerintah, sehingga kelanjutannya adalah bahwa penyuluh hanya memoles dan menyempurnakan tata manajemen keorganisasian, walaupun ada penyuluh yang mendirikan, membina dan membesarkan majlis taklim dan langsung menjadi top leader pada majlis taklim yang ia dirikan tersebut.

Terdapat penyuluh yang mampu memotivasi organisasi manajemen majelis taklim di lingkungannya dan memotivasi jama'ahnya. Penyuluh mampu membawa organisasi majelis taklim menjadi terbuka serta mampu mengakomodir menjadi penyambung dengan seluruh lapisan masyarakat, strata sosial dan strata pendidikannya. Atau bahkan penyuluh mampu mengklasifikasi kegiatannya proses belajar mengajar menjadi sistem klasikal, misalnya majlis taklim remaja, majlis taklim ibu-ibu dan majlis taklim bapak-bapak, disamping majlis taklim yang mengakomodir secara keseluruhan, yang dikemas dengan pengajian umum. Penyuluh tersebut mampu memanjemen majlis taklim dari segi waktu pelaksanaannya dan tempat penyelenggaraannya.

Banyak para penyuluh agama, baik penyuluh agama PNS maupun Non PNS belum memiliki pengetahuan yang memadai untuk mengembangkan fungsi majlis taklim, terutama fungsi pokok yakni sebagai lembaga da'wah dan lembaga pendidikan non-formal. Sehingga para penyuluh harus mampu mengetahui dan mengejawantahkan dari tersebut, karena dengan hal demikianlah majlis taklim menjadi sebuah kekuatan sehingga mampu bertahan dan menjadi lembaga pendidikan Islam yang paling dekat dengan umat (masyarakat). Majelis Ta'lim juga merupakan wahana interaksi dan komunikasi yang kuat antara masyarakat dengan para ustadz, dan antara sesama anggota jamaah majelis ta'lim. Kiranya faktor kemamuan dan kemampuan inilah 
yang harus dimiliki oleh para penyuluh agama kita.

Dengan demikian para penyuluh seyogyanya harus memilki pengetahuan yang mumpuni dalam memahamai dan dan harus menyadari betul tentang tugas pokok dan fungsinya sebagai penyuluh agama. Penyuluh harus mampu mendeskripsikan tugas pokok tersebut dalam kegiatannya, mampu mengaplikasikan metodologi dakwahnya, serta haru mampu mengembangkan manajerial majlis taklim di wilayahnya, sehingga para penyuluh layak menjadi inspirator dan motivator terhadap keberadaan majelis taklim.

\section{METODE PENELITIAN}

Dari latar belakang tersebut lalu muncul rumusan masalah diantaranya: Bagaimana peran penyuluh sebagai penggerak ekonomi, kemudian bagaimana peranan penyuluh sebagai penggerak ibadah sosial kemasyarakatan dan bagaimana peranan penyuluh terhadap kegiatan kegamaan terutama yang jarang dilakukan yakni tentang pembimbingan dan pendampingan pengurusan jenazah. Adapun tulisan ini menggunakan metodologi kualitatif deskriptif.

\section{TEMUAN DAN PEMBAHASAN}

\section{TEMUAN}

\section{PEMBAHASAN}

Penyuluh Agama adalah pembimbing umat beragama dalam rangka pembinaan mental, moral dan ketaqwaan kepada Tuhan Yang Maha Esa, dan Penyuluh Agama Islam, yaitu pembimbing umat Islam dalam rangka pembinaan mental, moral dan ketaqwaan kepada Tuhan Yang Maha Esa, Allah SWT, serta menjabarkan segala aspek pembangunan melalui pintu dan bahasa agama

Sedangkan penyuluh agama yang berasal dari PNS sebagaimana yang diatur dalam keputusan Menkowasbangpan No. 54/KP/MK.WASPAN/9/1999, adalah Pegawai Negri Sipil yang diberi tugas tanggung jawab, wewenang dan hak secara penuh oleh pejabat yang berwenang untuk melakukan kegiatan bimbingan atau penyuluhan agama Islam dan pembangunan melalui bahasa agama.

Dalam prakteknya, kegiatan keagamaan (baik pengajian, majelis taklim dan sejenisnya), merupakan kegiatan pengajaran atau pendidikan agama Islam yang paling fleksibel dan tidak terikat oleh waktu. la terbuka terhadap segala usia, lapisan atau strata sosial dan jenis kelamin, mulai anak-anak, remaja sampai dewasa. Waktu penyelenggaraannyapun bisa dilakukan pada pagi, siang, dan sore bahkan malam hari. Tempat pengajarannya bisa dilakukan di rumah, masjid, gedung dll. Selain itu, kegiatan keagamaan memiliki dua fungsi sekaligus, yakni sebagai lembaga dakwah dan sebagai lembaga pendidikan non formal.

Selanjutnya, perlu diketahui bahwa agama mempunyai kedudukan yang sangat penting dan mulia serta strategis untuk di syi'arkan, apalagi dijadikan sebagai landasan spiritual, moral dan etika dalam pembangunan nasional. Agama dalam kontek sebagai sistem seharusnya di fahami dan diamalkan oleh masing masing individu, keluarga dan masyarakat seta menjiwai kehidupan berbangsa dan bernegara. Maka pendidikan, pembangunan dan pengembangan agama harus mendapat perhatian yang besar, baik dalam penghayatan maupun pengamalannya.

Pembangunan bidang agama merupakan bagian yang integral dari pembangunan nasional dan azas pembangunan gama itu adalah keimanan dan ketakwaan yang merupakan penjabaran dan pengamalan dari Sila Ketuhanan Yang Maha Esa. Hakikatnya pembangun di bidang agama adalah inti dari pembangunan itu sendiri yang seharusnya mewarnai dan memberikan nuansa kepada pembangunan pada bidang-bidang lainnya.

Pendidikan agama tidak cukup di sekolah, akan tetapi perlu direalisasikan di tengah-tengah kehidupan ermasyarakat. 
Bahkan pendidikan agama pada masyarakat bisa menjadi faktor penentu terlaksananya nilai-nilai keagamaan dalam kehidupan sehari hari. Salah satu bentuk pendidikan agama pada masyarakat adalah melalui penyuluhan agama. Maka penyuluhan agama perlu ditingkatkan kualitas, intensitasnya sehingga mampu beradaptasi dengan tantangan-tantangan baru akibat perkembangan masyarakat yang dinamis. Melalui penyuluhan agama ini, diharapkan proses peendidikan agama pada masyarakat yang meliputi alih pengetahuan, alih metoda dan alih nilai diharapkan berlangsung secara intensif dan efektif.

Kualitas penyuluh agama perlu ditingkatkan antara lain dengan memberikan informasi yang diperlukan. Penyuluh agama adalah juru dakwah, penyampai risalah tauhid dan risalah kerasulan, muballigh, da'i, yang meupakan profesi suci dan mulya. Akan tetapi di dalam melaksanakan tugasnya itu terkadang menemui kendala-kendala serta hambatan plus tantangan.

Ungkapan penyuluh agama merupakan kalimat yang lazim dan tidak asing bagi kita, apalagi dalam dunia pendidikan. Disamping itu kita juga mengenal istilah bimbingan, dimana tujuan dan hakikatnya adalah sama, walaupun pengertiannya mengandung sedikit perbedaan, namun pengertinyannya saling melengkapi sehingga kedua kata itu tidak dapat dipisahkan, bahkan kita sering mendengar istilah bimbingan dan penyuluhan.

Dari pengertian tersebut kemudian dijabarkan kembali, bahwa penyuluhan dan bimbngan tersebut adalah berkenaan dengan agama, maka jadilah kalimat bimbingan dan penyulhan agama, yang pengertiannya adalah segala kegiatan yang dilakukan oleh seseorang dalam rangka memberikan bantuan kepada orang lain yang mengalami kesulitan-kesulitan rohaniah dalam kesulitan hidupnya. Bantuan tersebut dimaksudkan agar supaya orang tersebut mampu mengatasinya sendiri karena timbul kesadaran atau penyerahan diri terhadap kekuasaan Tuhan.

Kemudian penyuluh agama dalam kaitannya sebagai pemotivator majlis taklim adalah mempunyai pengertian bahwa profesi penyuluh agama mempunyai peranan sebagai motor penggerak sebuah lembaga dakwah sehingga lembaga dakwah tersebut benar berfungsi, bukan hanya label/merek di halaman masjid atau pondok pesantren saja akan tetapi berfungsi dan berperan sebagaimana mestinya.

Majlis taklim laksana sebuah kendaraan bermesin, kendaraan tersebut tak akan hidup dan berfungsi kecuali mempunyai bahan bakar yang cukup, maka bahan bakar inilah sebagai inti dari gerakan sebuah kendaraan, maka penyuluh agama tak ubahnya seperti kendaraan tersebut, ia menjadi inti penggerak sebuah organisasi dakwah seperti majlis taklim. Seorang penyuluh agama dituntut mempunyai keahlian dibidang dakwah, orang yang berprofesi sebagai muballigh (juru dakwah) maka sudah tentu ia sebagai penyuluh agama, akan tetapi penyuluh agama belum tentu berprofesi sebagai muballigh, karena profesi penyuluh merupakan motivator penggerak terhadap suatu kegiatan.

1. Peranan Penyuluh sebagai Penggerak Ekonomi Umat

Penyuluh Agama Islam memiliki peranan strategis dalam menggerakkan dan meningkatkan ekonomi umat, karena dengan ilmunya dan atau dengan kerjasama dengan fihak terkait penyuluh agama harus bisa dan mampu menyampaikan ilmu serta memberikan penyuluhan kepada masyarakat tentang pemberdayaan ekonomi umat muslim diwilayah binaan masing-masing. Hal ini harus dilaksanakan agar ekonomi umat pada umumnya dan khususnya jama'ah anggota majelis taklim binaannya menjadi berdaya, misalnya dengan mendirikan koperasi majelis taklim, yang tujuan dan peruntukannya adalah dari dan untuk anggota jama'ah majlis taklim.

Ekonomi harus menjadi kuat dan mandiri harus disampaikan penyuluh ke tengah-tengah masyarakat muslim agar masyarakat muslim terus berupaya menuju hal tersebut melalui wirausaha yang mandiri, menerapkan sistem perekonomian yang sesuai syariat Islam mengingat populasi umat Islam yang 
begitu besar dan merupakan masyarakat mayoritas di Indonesia. Melalui kegiatan meningkatkana peran serta penyuluh agama ini, tentunya dapat membantu ekonomi saudarasaudara kita sesama muslim dan melahirkan pengusaha muslim yang sukses. Hal ini dimungkinkan karena padanan kegiatan yang harus dilakukan penyuluh agama disamping melaksanakan tugas pokok dan fungsinya, bahwa penyuluh agama harus memiliki dedikasi tinggi dalam tugasnya, mempunyai keperdulian terhadap anggota majlis taklim dan masyarakat binaannya, memiliki rasa cinta terhadap sesama, suka bekerjasama, memiliki pengetahuan agama dan berakhlak mulia.

Integrasi antara dakwah dan ekonomi Islam dalam membangun nilai-nilai keperdulian nilainilai kemanusiaan, bersifat terbuka dan ulet dalam tugas ekonomi umat. Dengan demikian penyuluh agama mampu mendorong dalam mengaplikasikan pemberdayaan ekonomi umat melalui Majelis Taklim binaannya. Upaya yang dapat dilakukan oleh penyuluh adalah memadukan kelompok binaan dengan usaha kecil yang dapat di kembangkan sesuai dengan kondisi lokal masing-masing. Penyuluh agama mampu menstimulus dan memanfaatkan iuran majelis taklim jama'ahnya untuk model usaha pengembangan ekonomi umat, memanfaatkan bantuan pemerintah dan swasta untuk dijadikan modal pengembangan ekonomi umat melalui koperasi simpan pinjam dan semisalnya, atau kantin dan warung manisan/sembako. Bahkan dalam melaksanakan program perberdayaan ekonomi umat tersebut penyuluh agama melakukan bekerjasama dengan lembaga Islam yang mengelola perekonomian Umat seperti Baznas, Badan Wakaf, Ruamah Zakat, Lazis pada organisasi Muhammadiyah atau Bazis pada organisasi Nahdhatul Ulama, dll.

2. Peranan Penyuluh sebagai Penggerak Ibadah Sosial

Dimaklumi, bahwa penyuluh adalah Aparatur Sipil Negara yang diberikan wewenang untuk menggerakkan majlis taklim sebagai tempat pembelajaran dan pengkajian serta pegamalan nilai-nilai ajaran Islam, termasuk di dalamnya ibadah kemasyarakatan atau ibadah sosial. Hal ini semua dilakukan dalam rangka meningkatkan pengetahuan, pemahaman, dan pengamalan ajaran Islam terhadap anggota atau jama'ah majlis taklim. Majlis taklim dalam fungsinya sebagai lembaga pendidikan dan keterampilan juga berfungsi sebagai lembaga pendidikan dan keterampilan yang berhubungan dengan pengembangan kepribadian serta pembinaan keluarga dan rumah tangga sakinah, mawaddah dan rahmah, serta kehidupan bermasyarakat. Peran penyuluh agama fungsional harus mampu merombak dan mengubah image bahwa majlis taklim bukan hanya tempat mendalami dan mengamalkan ritual keagamaan saja, akan tetapi harus mampu menjadi agent of change dalam mengembangkan peradaban Islam yang moderat dan rahmatan lilalamin.

Penyuluh agama sudah seyogyanya mengembangkan majlis taklim menjadi pusat pengembangan peradaban dan pengembangan kualitas sumber daya manusia dalam berbagai bidang, baik dalam bidang dakwah, pendidikan, sosial, bahkan politik. Mampu menjalin jejaring komunikasi sosial ke arah yang lebih baik, menjdikan majlis taklim menjadi sarana ukhuwah Islamiah, sarana dakwah, dan mampu mengembangkan potensi diri secara self standing dan self disciplined. Penyuluh mampu mengatur dan melaksanakan berbagai kegiatan berdasarkan musyawarah untuk mufakat demi untuk kelancaran pelaksanaannya. Penyuluh Agama sebagai Pembimbing dan Pendampingan Pengurusan Jenazah

Penyuluh agama, selain bertugas sebagai pembimbing keagamaan bagi nggota jama'ah majlis taklim sebagai binaannya juga bagi warga masyarakat, mesti bertugas sebagai konselor yang selalu siap mendengarkan dan memberikan solusi dan pencerahanpencerahan atas permasalahan masyarakat yang berhubungan dengan keagamaan. Untuk itu, seorang penyuluh agama harus memiliki kecakapan sebagai seorang konselor yang handal dan bukan hanya fasih sebagai seorang penceramah, termasuk harus mampu memprogramkan 
kegiatan ibadah kemasyarakatan yang bersifat fardhu kifayah, dengan detail dan secara komprehensif yakni melakukan pembimbingan dan pendampingan pengurusan jenazah, dari mulai memandikan, membungkus, menyalatkan dan menguburkan. Bahkan pembelajaran tentang kewajiban pra kematian (tata cara mentalqin) sampai kepada pasca penguburan.

Terlebih lagi pada saat ini, manakala sedang mewabahnya penyakit menular virus corona atau lebih dikenal dengan covid-19. Penyuluh agama harus mampu dan mumuni serta menguasai ilmu fikih tentang proseur pengurusan jenazah covid-19. Penyuluh agama harus mampu memberikan pendampingan dan erlibat langsung dalam pengurusan dan pemulasaraan jenazah covid-19.

Sebut saja misalnya seorang penyuluh agama dari Mataram NTB benama Rahmi mengemukakan bahwa la bersama empat penyuluh agama honorer alainnya menceritakan bahwa pada masa pandemi covid 19, dirinya telah menyiapkan diri untuk melayani masyarakat, salah satunya memberikan kesediaan untuk mengurus jenazah pasien yang terpapar covid-19. Terutama kami mengurus pasien yang ODP. Karena kalau jenazah berstatus Pasien Dalam Pengawasan, sesuai protokol diurus langsung oleh pihak rumah sakit. Menurutnya peran penyuluh agama sebagai pendamping masyarakat amatlah penting di tengah pandemi covid-19 ini. la sadar kehadirannya di tengah masyarakat akan meringankan beban psikologis masyarakat untuk menghadapi pandemi.

\section{PENUTUP}

\section{Simpulan}

Seorang penyuluh agama dituntut agar mampu memberikan penyuluhan kepada masyarakat, bukan hanya berkutat dalam memberikan bimbingan pendidikan keagaman dan ibadah ritual saja, akan tetapi dituntut untuk lebih mengembangkan sumber daya yang dimiliki untuk mengembangkan programprogramnya dengan lebih universal menyeluruh dan kaffah. Penyuluh agama harus mampu menjadi penggerak majlis taklim sebagai lembaga dan wadah pembinaannya menjadi penggerak dalam memberdayakan majlis taklim menjadi penggerak ekonomi umat, semisal mendirikan dan mengembangkan koperasi majlis taklim dengan melibatkan unsur terkait.

Selain program tersebut, penyuluh agama juga harus mampu menjadi penggerak ibadah sosial kemasyarakatan, mampu menjadikan profesi dirinya sebagai penyuluh yang profesional, menjadi agen perubahan bagi dirinya dan bagi majlis taklim sebagai sentra pembangunan peradaban Islam yang lebih maju dan komprekhensif.

Kemudian penyulh juga mampu mengembngkan potensi dirinya untuk menjadi pendampingan dalam ibadah kemasyakatan yang lain, seperti halnya menjadi pembimbing dan melakukan pembimbngan bahkan terjun langung menjadi pengurus jenazah yang terpapar covid-19.

\section{Rekomendasi}

a. Peyuluh agama hendaknya mampu mengembangkan potensi dirinya dalam kapasitas sebagai penyuluh untuk mengembangkan dari kegiatankegiatan yang stagnan dan terkesan baku ke dalam kegiatan-kegiatan pengembangan pemberdayaan anggota majlis taklim binaan dan masyarakat pada ummnya.

b. Penyuluh agama henduknya mampu dan berusaha untuk memberikan pembimbingan dan pendampingan dalam menanggulangi wabah covid-19, bahkan menjadi pengurus jenazah pasien yang terpapar vovid-19. 


\section{DAFTAR PUSTAKA}

Abdullah, Abdul Gani. (1994). Pengantar Kompilasi Hukum Islam dalam Tata Hukum Indonesia. Gema Insani.

Aizid, Rizem. (2018). Figh Keluarga Terlengkap. LAKSANA.

Al-Juzairy, Abdurrahman. (2014). Al-Figh 'ala al-Mazahib al-Arba'ah. Kairo: Dar al-Jauzy.

Al-Zuhaili, Wahbah. t.t. DR., al Fiqh al Islamy Wa Adillatuhu. Bairut, Dar al Fikr, cet. IV.

Dahlan, Djamaludin Arra uf bin. (2011). Aturan Pernikahan Dalam Islam. Lembar Langit Indonesia.

Ghazaly, H. Abdul Rahman. (2019). Figh munakahat. Prenada Media.

Ghofiri, Hafidz al-. (2017). "Konsep besarnya mahar dalam pernikahan menurut Imam As-Shafi'i." PhD Thesis, IAIN Ponorogo.

Kementerian Agama, R. I. (2013). "Tafsir Alqur'an The Great Miracle." Solo. PT Tiga Serangkai Pustaka Mandiri.

Sabiq, Sayyid. (1987). "Fiqh Sunnah, terj." Kamaluddin A. Marzuki. Bandung: Al Ma'arif.

Sudarto, M. Pd I. (2020). FIKIH MUNAKAHAT. Penerbit Qiara Media.

Supriyadi, Dedi, dan Beni Ahmad Saebani. (2015). "Fiqh Munakahat Perbandingan: dari tekstualitas sampai legitimasi."

Tihami, H. M. A., dan Sohari Sharani. (2009). Fikih Munakahat, Kajian Fikih Nikah Lengkap. Jakarta: PT.” Raja Grafindo Persada. 